Rasoolimanesh, M., Taheri, B., Gannon, M., Vafaei-Zadeh, A. \& Hanifah, H. (2019). Does living in the vicinity of heritage tourism sites influence residents' perceptions and attitudes? Journal of Sustainable Tourism (forthcoming).

\title{
Does living in the vicinity of heritage tourism sites influence residents' perceptions and attitudes?
}

\begin{abstract}
This study investigates whether the perceptions and attitudes of residents living within the vicinity of heritage tourism sites differ from those living further afield. It examines residents' attitudes toward tourism development; community attachment; local environment and culture; economic gain; and involvement, alongside the moderating role of distance from heritage tourism sites. In doing so, it investigates how the aforementioned factors influence residents' perceptions of tourism development in their city. Data was collected from inhabitants of Kashan and Tabriz, two historic cities couched within Iran's growing heritage tourism sector, and analyzed using partial least squares structural equation modeling (PLS-SEM). The findings demonstrate significant differences between the perceptions of tourism impacts, economic gain, environmental and cultural attitudes, and involvement between residents living within the vicinity of heritage tourism sites and those living further afield. However, these findings contradicted the hypotheses; identifying higher positive perceptions, environmental and cultural attitudes, economic gain, and involvement for residents living far from heritage tourism sites. Further, the findings did not support the moderating role of distance for the effects of influencing factors on residents' perceptions. Therefore, this study proffers significant theoretical contributions and practical implications with regards to developing sustainable tourism in Iran.
\end{abstract}

Keywords: Residents’ perceptions; distance from tourism sites; vicinity to tourism sites; moderating effects; heritage tourism; Iran 


\section{Introduction}

Grounded by a range of theoretical frameworks, research has long investigated the factors that influence residents' perceptions of tourism development within their local communities (Andereck et al., 2005; Ap, 1990, 1992; Besculides et al., 2012; Látková \& Vogt, 2012; Li \& Wan, 2017; Olya \& Gavilyan, 2017; Rasoolimanesh et al., 2015). However, the moderating role that distance from heritage tourism sites plays in shaping residents' perceptions has seldom been investigated, with little consensus in nascent results (Jurowski \& Gursoy, 2004; Khoshkam et al., 2016). For example, some studies suggest that those living in the vicinity of tourism sites hold more favourable opinions of the impact of tourism than those living further afield (Jurowski \& Gursoy, 2004), whereas others contend the opposite (Pizam, 1978).

Yet, while the role residents' perceptions play in achieving sustainable tourism development and management has been discussed across extant literature (Nicholas et al., 2009; Rasoolimanesh \& Jaafar, 2017; Telfer \& Sharpley, 2008), emphasis is often placed on those living inside or within the immediate vicinity of tourism sites. Residents geographically proximate to such sites are exposed more regularly to tourists, with positive perceptions of tourism development likely to encourage constructive interactions, further supporting tourism development in the process (Jurowski \& Gursoy, 2004). Alternatively, first-hand experiences of the negative impacts of tourism can influence site sustainability as residents' support for tourism development deteriorates (Látková \& Vogt, 2012; Matarrita-Cascante et al., 2010).

Further, despite the established role residents play in shaping and supporting sustainable tourism development, few studies consider the influence of their perceptions in marginal or emergent contexts. This study therefore compares the perceptions of residents (i) living within the vicinity of heritage tourism sites, and (ii) living far from heritage tourism sites in two historic Iranian cities: Kashan and Tabriz. The heritage tourism context provides an interesting backdrop for research into residents' perceptions of tourism development, as the need to conserve and protect heritage assets competes with a desire to craft competitive tourism offerings (MacKenzie \& Gannon, 2019). As such, while heritage reflects the values and identity of local communities, increased emphasis on inbound tourism can raise international awareness of local traditions and values, financially safeguarding tangible assets 
in the process (Rasoolimanesh et al., 2017b). Further, this study considered two different study areas to cross-validate the results, with both Kashan and Tabriz recognized for their distinct and distinguished heritage offerings, couched within the rapidly developing Iranian tourism sector (Taheri et al., 2019).

This study also considers whether the moderating role of distance from heritage tourism sites influences the effect of community attachment, environmental attitudes cultural attitudes, economic gain, and involvement on residents' perceptions toward tourism development. It examines whether these effects differ significantly between residents living within the vicinity of, and those living further from, heritage tourism sites. To the best of our knowledge, this is the first attempt to compare the perceptions of residents living in the vicinity of heritage sites with those living far from heritage tourism sites in historic Iranian cities, further contributing to extant understanding of tourism development in emerging markets. Heritage tourism in Iran is characterised by a large volume of diverse, historic, culturally significant attractions; providing an interesting case study characterized by the complex convergence of locality, identity, connectivity, and tourism development (Thompson et al., 2018). Thus, Iran represents an under-researched, emerging tourism domain rich in internationally recognized heritage assets (Gannon et al., 2019). We applied partial least squares - structural equation modeling (PLS-SEM), including some advanced contemporary analytical techniques, to analyze the collected data.

\section{Theoretical framework}

While a range of overarching theories have been used to develop an understanding of residents' perceptions toward tourism development, Social Exchange Theory (SET) continues to dominate discourse (Ap, 1990, 1992; Látková \& Vogt, 2012; Rasoolimanesh et al., 2017a; Sharpley, 2014). Emerson (1976, p.336) defined social exchanges as "two-sided, mutually contingent, and mutually rewarding processes involving 'transactions'”. Hospitality and tourism industry stakeholders pursue these exchanges when the benefits associated with relationships are equal to or greater than the perceived cost of the exchange (Thompson et al., 2018). As such, the principles of SET suggest that residents are likely to support tourism development in their local communities if the perceived benefits outweigh its costs. Conversely, if anticipated to incur greater costs than benefits, residents are less inclined to support tourism development (Manyara \& Jones, 2007; Jurowski et al., 1997; Rasoolimanesh et al., 2015). 
To this end, Lawler, Thye and Yoon (2008) proposed two forms of exchange: negotiated and reciprocal. Here, "negotiated exchange is a multilateral engagement where parties explicitly decide upon the terms of exchange in order to construct mutually beneficial relationships...Reciprocal exchange...is sequential...devoid of any immediate implication to return the exchange but relies on one party to reciprocate” (Thompson et al., 2018, p.1208). Contemporary tourism development is underpinned by reciprocal and negotiated exchanges; successful, sustainable tourism sites promote interface between multiple stakeholders (including different resident groups) in order to encourage them to engage in mutually beneficial behaviors. This can develop destinations' tourism offerings more generally (negotiated exchange), while encouraging residents to recommend attractions outside of their vicinity to inbound tourists, irrespective of any immediate benefit to oneself (reciprocal exchange).

There is thus broad support for the use of SET as a basis for understanding residents' attitudes (Boley et al., 2014; Moghavvemi et al., 2017; Olya \& Gavilyan, 2017; Woosnam et al., 2018; Zuo et al., 2017), as it "can account for both the positive and negative impacts of tourism as perceived by the host community" (Ap, 1992, p.685). Nunkoo, Smith, and Ramkissoon (2013, p.6) argue its relevance as it "recognizes the heterogeneous nature of a host community, where different groups may hold different attitudes to tourism, depending on their perceptions of the industry's benefits and costs".

However, SET is by no means infallible, with recent studies criticizing its efficacy in justifying the effects of influencing factors on residents' perceptions (Sharpley, 2014; Woosnam, 2011). To support the effects of influencing factors, SET should be able to explain the reasons behind these effects (Rasoolimanesh et al., 2015). Yet, some question SET's ability to do so (Woosnam, 2011). In response, studies have considered SET from an interpersonal exchange perspective (Cropanzano \& Mitchell, 2005; Rasoolimanesh et al., 2015; Rasoolimanesh et al., 2017b), while continuing to hypothesize factors influencing residents' perceptions framed by the six central rules of SET.

Meeker (1971) introduced these rules (reciprocity, rationality, altruism, group gain, status consistency, and competition) to explain the decline of tourism development, alongside the role that residents' perceptions play in shaping tourism development. The reciprocity rule echoes traditional understanding of SET, highlighting the mutual exchange between residents and tourists, and emphasising that residents' support for tourism development in their local community is contingent upon the returns they expect to receive (Ap, 1992). These returns can be tangible (e.g., financial gain, economic development, improved amenities) or 
intangible (e.g., prestige, social status), but can empower residents by developing communal goals (Cropanzano \& Mitchell, 2015; Rasoolimanesh et al., 2017b). Reciprocity stems from this sense of community; if residents perceive that tourism development will be of greater benefit to the community (and themselves) than its anticipated costs, they will support it. However, residents are less likely to support tourism development if they believe the associated costs outweigh any potential benefits (Jurowski et al., 1997; Rasoolimanesh et al., 2015).

The rationality rule echoes Weber's theory of substantive and formal rationality, which some suggest offsets the limitations of SET (Andereck et al., 2005; Boley et al., 2014). This rule can support factors linked to both formal (e.g., economic gain) and substantive rationality (e.g., values and beliefs) (Rasoolimanesh et al., 2017c). Residents' values and beliefs, including their environmental and cultural attitudes toward: heritage assets, traditional events, costumes and foods, and the contribution of tourism in preserving these assets, may thus influence their perceptions (Andereck et al., 2005; Rasoolimanesh et al., 2015). To this end, Zuo et al. (2017, pp.51-52) claim that "in hierarchical societies where substantive rationality is common, social and cultural structures lead to greater acceptance of authoritarian decision making whereby residents' supportive behaviour is not solely based on the calculation of material interests but may depend more on faith in and affection for the government, or a combination of the two”. Thus, the importance of value-laden cultural attitudes can shape residents' perceptions of tourism development, particularly in hierarchical contexts (e.g., Iran) where residents hold little influence over the decision to undertake tourism development in the first place.

The altruism rule suggests that residents can perceive personal costs and negative impacts from inbound tourism. However, they also recognize the benefits tourism provides to others within the wider community, which can influence their support for tourism development (Manyara \& Jones, 2007; Rasoolimanesh et al., 2015; 2017b). This altruism is underpinned by actions that benefit other community members irrespective of personal cost or gain (Rasoolimanesh et al., 2015). Similarly, the group gain rule refers to community benefits instead of personal gain. Therefore, underpinned by group gain, residents may support tourism development if they believe that inbound tourism supports and benefits their community (Cropanzano \& Mitchell, 2005). Rasoolimanesh et al. (2017b, p.201) thus argue that "according to the altruism and group gain rules of SET, residents may express interest in doing something for the benefit of the community and other individual community members despite whatever personal costs might be incurred”. 
Status consistency is characterized by attachment to a particular group (e.g., nationality, ethnicity, culture, gender). If residents believe that tourism benefits the group they belong to, they are more likely to support tourism development. Conversely, if tourism is likely to do harm to their peers, they will not support local tourism development (Cropanzano \& Mitchell, 2005; Rasoolimanesh et al., 2017b). Nonetheless, underpinned by a desire to preserve traditions and identity, residents may wish to showcase cultural assets to tourists in order to foster "cultural pride [which can therefore] influence the development of the local tourism industry as local communities feel that they have something valuable to offer the tourist” (Rasoolimanesh et al., 2017b, p.202). Finally, the competition rule serves as the antithesis of the altruism rule, suggesting that resident behavior can be motivated by the pursuit of benefit regardless of cost, consequence, or impact upon oneself or others (Cropanzano \& Mitchell, 2005; Rasoolimanesh et al., 2015). To this end, the competition rule recognizes that sometimes "individuals act against others irrespective of what harm they might incur unto themselves” (Rasoolimanesh et al., 2017b, p.200).

Thus, the six underlying rules of SET provide a strong theoretical basis from which to conceptualize and determine the effects of antecedent factors on residents' perceptions toward, and support for, tourism development (Rasoolimanesh et al., 2015). This study, cognizant of Meeker's (1971) rules, thus aims to gain deeper understanding of how influencing factors influence residents' perceptions by considering whether differences exist in these effects between residents (i) living in the vicinity of, and (ii) living far from tourism sites.

\section{Conceptual framework and research hypotheses}

Several studies have investigated the role of community attachment in shaping residents' perceptions of tourism development, with this predominantly positive effect consistent with SET's altruism, group gain, and status consistency rules (Besculides et al., 2012; Nicholas et al., 2009; Olya \& Gavilyan, 2017; Tosun, 2002; Látková \& Vogt, 2012; Rasoolimanesh et al., 2015). Moghavvemi et al. (2017, p.244) argue that “residents' level of community attachment has the capability to predict attitudes about tourism development [as] residents who are strongly committed to their community are more involved and exposed to tourism impacts”. Thus, residents living within the immediate vicinity of tourism sites may hold greater interest in, and attachment to, their community and heritage assets therein, and may be more positive about the impact and contribution of tourism to their community. 
The notion that residents living within the vicinity of heritage sites may hold more favourable perceptions of the impacts of tourism is supported by the aforementioned group gain, altruism, and status consistency rules. As tourism can contribute to the conservation and promotion of culture and heritage assets, residents living within or close to heritage sites may feel a greater sense of belonging and attachment to assets considered important to their communities, supporting tourism development in the process. As such, community attachment may exert a stronger positive effect on residents' perceptions for those living within the vicinity of heritage tourism sites compared to those living further afield. Thus:

H1: Community attachment is stronger among residents living within the vicinity of heritage tourism sites.

H2: The effect of community attachment on residents' perceptions is stronger for residents living within the vicinity of heritage tourism sites.

As mentioned prior, SET's rationality rule suggests that residents' beliefs and values can positively influence their perceptions. Residents with stronger cultural and environmental attitudes may welcome increased tourism due to its ability to promote their values and traditions, alongside its potential for preserving tangible heritage assets (Moghavvemi et al., 2017; Woosnam et al., 2018; Zuo et al., 2017). Residents living within the vicinity of heritage tourism sites may hold more favourable attitudes toward the preservation and conservation of local heritage compared to those living far from heritage tourism sites due to their increased exposure to these assets (Mackenzie \& Gannon, 2019). Indeed, echoing the principles of the rationality rule, literature identifies that residents are likely to perceive the potential impacts of tourism in a more positive light if they hold stronger environmental and cultural attitudes toward their local heritage sites, supporting tourism development in the process (Nicholas et al., 2009; Rasoolimanesh et al., 2017b). Therefore:

H3: Environmental attitude is stronger for residents living within the vicinity of heritage tourism sites.

H4: The effect of environmental attitude on residents' perceptions is stronger for those living within the vicinity of heritage tourism sites.

H5: Cultural attitude is stronger for residents living within the vicinity of heritage tourism sites. 
H6: The effect of cultural attitude on residents' perceptions is stronger for those living within the vicinity of heritage tourism sites.

The potential for economic gain can also shape residents' perceptions (Boley et al., 2014; Jurowski et al., 1997; McGehee \& Andereck 2004; Rasoolimanesh et al., 2017a, 2017d; Sirakaya et al., 2002; Zuo et al., 2017). Residents likely to derive economic benefit from tourism typically favour and support tourism development. Those living in closer proximity to heritage tourism sites are perhaps more likely benefit financially from inbound tourism, and may thus support local tourism development (McGehee \& Andereck 2004; Rasoolimanesh et al., 2017c; Zuo et al., 2017). This is consistent with SET's rationality and competition rules, which suggest that residents best-placed to benefit from tourism are likely to hold stronger positive perceptions the impact of tourism, supporting tourism development in the process (Rasoolimanesh et al., 2015). Given their proximity to heritage assets, residents living within the vicinity of heritage tourism sites may be better positioned to take advantage of the potential economic boon of inbound tourism and the associated increase in inward investment in the local community (MacKenzie \& Gannon, 2019). Therefore:

H7: Economic gain is stronger for residents living within the vicinity of tourism sites.

H8: The effect of economic gain on residents' perceptions of tourism development is stronger for those living within the vicinity of tourism sites.

A sense of community involvement can empower residents, allowing them to contribute to (and exert perceived control over) the tourism development process. It can temper the perceived negative impacts of increased tourism (Andereck \& Nyaupane, 2011; Nicholas et al., 2009; Látková \& Vogt, 2012; Tosun, 2002; Rasoolimanesh et al., 2017c), increasing residents' awareness of the benefit of tourism development (Rasoolimanesh et al., 2015; Tosun, 2002; Zuo et al., 2017). Resident involvement in the tourism development process can benefit the local community; by providing a consistent, sympathetic voice residents can ensure that the promotion and conservation of indigenous culture, identity, and heritage are recognized by tourism planners (Rasoolimanesh et al., 2017d). Therefore, residents with greater involvement in the tourism development process are often more positive about the impact tourism can have on their community (Andereck \& Nyaupane, 2011; Nicholas et al., 2009). To this end, the rationality, group gain, and status consistency rules support the positive effect involvement plays in shaping residents' perceptions of tourism development. 
However, tourism planners often primarily consult locals residing within the immediate vicinity of heritage tourism sites. This stems from a belief that they play a more significant role in supporting tourism development than those who are detached from tourism sites or who live far from these sites (Tosun, 2002). Therefore, due to potential greater involvement in the tourism development process, those residing within the vicinity of heritage tourism sites may champion and support increased inbound heritage tourism to a greater extent. Thus:

H9: Involvement in tourism activities and decision-making is higher among residents living within the vicinity of tourism sites.

H10: The effect of involvement on residents' perceptions of tourism development is stronger for residents living within the vicinity of heritage sites.

Finally, as residents living within the vicinity of tourism sites may be better placed to benefit from inbound tourism they may be hold a more favourable opinion on the impact of tourism development (Jurowski \& Gursoy, 2004; Mansfeld, 1992). Consistent with the rationality rule, those likely to benefit most from inbound tourism may therefore demonstrate stronger support tourism development (Rasoolimanesh et al., 2015). Thus, this study hypothesizes that residents living within the vicinity of heritage tourism sites hold more positive perceptions toward tourism development than those living far from such sites:

H11: The perceptions of residents toward tourism development are more positive for residents living within the vicinity of tourism sites.

Figure 1 shows the conceptual framework underpinning this study, demonstrating the hypothesized relationships.

\section{[Figure 1 here]}

\section{Methodology}

\section{Study area}

Data was collected from residents of two Iranian cities: Tabriz and Kashan. An historic city, Tabriz serves as the capital of Iran's East Azerbaijan Province, and is endowed with several heritage sites, many of which date back over 2500 years. The city has several tangible and intangible heritage assets including: the Tabriz Historic Bazaar Complex, Amir Nezam House, the Blue Mosque, the Constitutional Revolution House, and the Aji Chay Bridge. 
Further, its traditional carpet and craft industry has branded Tabriz one of the world's carpet and rug capitals. The city's commitment to heritage is clear; as a mainstay of the historic Silk Road, the Tabriz Bazaar Complex has served as the commercial center of the province since the 13th century and remains one of the world's largest and best-preserved examples of a traditional marketplace (Curran et al., 2018), receiving UNESCO World Heritage Site inscription in 2010 (UNESCO, 2019).

Kashan also holds historic provenance. Located in central Iran and, based on evidence gathered from the remnants of prehistoric civilization found at Tepe Sialk, it is thought to date back to 6000 BCE (de Planhol, 2012). Echoing Tabriz, Kashan boasts ample tangible and intangible heritage assets, including: historical houses (e.g. Broujerdi, Tabatabaei, Abbasian, Ameri), Bazar-e-Kashan, mosques (e.g. Agha Bozorg, Jameh), and traditional carpets and handicrafts. Overall, Kashan is home to 323 recognized tangible assets and nine intangible assets inscribed as national cultural heritage (ICHTO, 2017). Further, the Bagh-e Fin (alongside eight other gardens) was inscribed as a UNESCO World Heritage Site (the 'Persian Gardens') in 2011. Additionally, the Qālišuyān rituals of Mašhad-e Ardehāl and Kashan carpet weaving were designated as world intangible cultural heritage in 2012 and 2010 respectively (UNESCO 2017a, 2017b).

\section{Data collection}

This study employed a quantitative approach, using a questionnaire, to collect data from residents in Tabriz and Kashan. Data was collected from two different cases to cross-validate results. Based on previous literature, the questionnaire measured the perceived economic (4items), environmental (3-items), and socio-cultural impact of tourism development (4-items) (Jurowski et al., 1997; Rasoolimanesh et al., 2019); alongside residents' community attachment (4-items) (Gursoy et al., 2002; Nicholas et al., 2009), environmental attitudes (3 items) (Nicholas et al., 2009; Rasoolimanesh et al., 2015), cultural attitudes (3-items) (Rasoolimanesh et al., 2017b), economic gain (2-items) (Jurowski et al., 1997; Rasoolimanesh et al., 2017c), and involvement (3-items) (Nicholas et al., 2009; Rasoolimanesh et al., 2017b).

Respondents indicated their agreement with statements using a five-point scale (1 'Strongly Disagree'; 5 'Strongly Agree’). The questionnaire was translated from English into Farsi by native bilingual researchers. Prior to data collection, back-translation was employed to confirm the meaning of items and to avoid misinterpretation (Gannon, Taheri \& Olya, 
2019). A pilot test was conducted with five experts and 35 respondents, with some questionnaire items reworded or removed accordingly.

Data was collected in late 2017 (Kashan) and early 2018 (Tabriz), using systematic cluster sampling. Overall, 404 and 515 completed questionnaires were collected from residents in Kashan and Tabriz respectively at two core heritage tourism sites, and two other clusters far from these sites. Of the Kashan sample, 226 questionnaires were collected from residents living within the vicinity of the two selected heritage sites, and 178 from residents living in two other clusters, far from the city’s heritage sites. For Tabriz, 296 responses were collected from those living within/in close proximity to heritage tourism sites, with 219 responses collected from residents living further afield. Vicinity was defined based on documents of inscription published by the Iranian Cultural Heritage, Handicrafts and Tourism Organization (ICHTO). Each ICHTO-recognized site is distinguished by core and buffer zones, with these zones signifying residents' vicinity to heritage tourism sites. Therefore, this study classifies residents' vicinity to heritage tourism sites based on the core and buffer zones outlined by the ICHTO; residents considered living 'far' from heritage tourism sites lived outside of these zones. Thus, two heritage sites were selected in each city, with data collected from residents living within the core and buffer zones of these sites, and from two areas elsewhere in each city, outside of these zones.

Of the 404 respondents from Kashan, 62.1\% were male. Respondents were categorized into five age groups: 15-25 (12.1\%), 26-35 (38.6\%), 36-45 (30.2\%), 46-55 (12.6\%) and 56+ (6.4\%). Most respondents from Kashan had completed a diploma or degree (65.1\%), 17.1\% were educated to a postgraduate level, and $17.8 \%$ had completed secondary and primary school or had no formal education. For Tabriz, 58.6\% of respondents were male. The 515 respondents from Tabriz were also categorized into five age groups: 15-25 (11.7\%), 26-35 (39.2\%), 36-45 (31.3\%), 46-55 (12.0\%) and 56+ (5.8\%). Regarding education, 64.6\% of respondents from Tabriz had completed a diploma or degree, with $17.3 \%$ postgraduate educated, and $18.1 \%$ completing secondary or primary school, or holding no formal education.

The existence of Common Method Variance (CMV) was also investigated. Participants were informed that all responses remained anonymous, minimizing social desirability bias. Independent and dependent constructs were positioned in different areas of the questionnaire. Harman's single-factor test evaluated CMV by entering all constructs into a principal component analysis (PCA) (Gannon et al., 2017). For the data collected from 
Tabriz, the eigenvalue unrotated PCA solution detected 6 factors, and the highest portion of variance explained by one single factor was 35.501\%. For Kashan, the eigenvalue unrotated PCA solution detected 6 factors, and the largest portion of variance described by one single factor was $23.5 \%$. The unmeasured method factor approach suggested by Min et al. (2016) was employed to further examine CMV. Further, following Liang et al.'s (2007) recommendation for partial least squares structural equation modeling (PLS-SEM), a common method factor was presented to the structural model. The average variance illustrated for Tabriz was 61\%, whereas the average method-based variance was 1.5\% (40:1). For Kashan, the average variance explained by indicators was 67\%, while the average method-based variance was $1.4 \%$ (47:1). Hence, CMV is not a concern.

\section{Data analysis}

Data analysis was performed using SPSS24.0 and SmartPLS3.2.7 (Ringle et al. 2015). PLSSEM was used to assess the measurement and structural models. Multi-group analysis (MGA) was also used to compare the effects of the antecedent constructs on residents' perceptions between those (i) living in the vicinity of, and (ii) living far from heritage tourism sites in both cities. PLS-SEM was employed as non-parametric SEM is more appropriate when conducting MGA (Hair et al. 2017; Henseler et al. 2016). Prior to MGA and hypotheses testing, measurement invariance was evaluated using the measurement invariance for composite (MICOM) approach (Henseler et al., 2016). Two nonparametric methods were employed to run MGA: Henseler's MGA (Henseler et al., 2009) and the permutation test (Chin \& Dibbern, 2010). Further, a series of $t$-test analyses (using SPSS) were performed to evaluate differences in community attachment, cultural and environmental attitudes, economic gain, involvement, and perceptions toward tourism development between residents (i) living within the vicinity and (ii) living far from heritage tourism sites in both Kashan and Tabriz.

An appropriate sample size for each group of residents was required to perform the necessary hypothesis testing and analyses. According to Reinartz et al. (2009), a sample of 100 can satisfy the requirements of PLS-SEM, achieving the necessary power (0.8). Moreover, G*Power was used to calculate the minimum sample size based on power analysis (Faul et al., 2009; Hair et al., 2017). The G*Power results demonstrate that the minimum sample size required to generate a power of 0.95 for the proposed framework and for each resident group was 138 respondents. Therefore, the data collected from Kashan and Tabriz surpassed the level required to run analysis in this study. 


\section{Results and findings}

\section{Model assessment using PLS-SEM}

Assessment of measurement model and invariance measurement across two groups

The measurement model was assessed in two stages. First, all reflective exogenous constructs (community attachment (CAC), environmental attitude (EAT), cultural attitude (CAT), economic gain (ECG), involvement (INV)), and the three reflective dimensions of residents' perceptions (RP) (economic perceptions (ECO_RP), environmental perceptions (ENV_RP), and socio-cultural perceptions (SCUL_RP), were assessed in accordance with their reliability and validity. Next, using a two-stage approach (Becker et al., 2012), RP was established as a second-order composite construct by applying the score of ECO_RP, ENV_RP, and SCUL_RP from the first stage (Taheri et al., 2018), which assessed five reflective exogenous constructs and one composite endogenous construct for both (i) residents living within the vicinity of heritage tourism sites (at both Kashan and Tabriz), and (ii) residents living far from these sites (again, at both Kashan and Tabriz).

For both groups, measurement model assessment was conducted on data collected at two different heritage sites to cross-validate the results. To assess the reliability and convergent validity of the eight reflective measurement models, the outer loadings of associated items for each construct, composite reliability (CR), and average variance extracted (AVE) were examined (Hair et al., 2017). To establish reliability and convergent validity, outer loadings should be $>0.7$, CR $>0.7$, and AVE $>0.5$. Loadings $>0.5$ and $<0.7$ are acceptable if CR and AVE meet the threshold (Hair et al., 2017). Tables 1 and 2 demonstrate that the results for all reflective constructs are acceptable, with reliability and convergent validity established for each group of residents in both cities.

\section{[Table 1]}

\section{[Table 2]}

Next, discriminant validity was established for the Kashan and Tabriz sample. Tables 3 and $\mathbf{4}$ show the discriminant validity assessment results for residents living within the vicinity of tourism sites, and those living far from such sites, using the heterotrait-monotrait (HTMT) approach (Henseler et al., 2015; Voorhees et al., 2016). HTMT was applied as recent literature suggests that the traditional Fornell-Larcker criterion has shortcomings (Henseler et al., 2015), with the more conservative HTMT capable of providing a more robust assessment of 
discriminant validity: "HTMT is defined as the mean value of the item correlations across constructs relative to the (geometric) mean of the average correlations for the items measuring the same construct” (Hair et al., 2019, p.9). To establish discriminant validity via HTMT, literature suggests thresholds of either 0.85 or 0.9 (Henseler et al., 2015). The more conservative HTMT.85 has been applied in this study, with Table $\mathbf{3}$ and $\mathbf{4}$ demonstrating acceptable discriminant validity for both groups in both study areas.

\section{[Table 3]}

\section{[Table 4]}

Multi-collinearity was assessed using variance inflation factors (VIF) for the three items comprising the second-order 'residents' perceptions' composite construct and the significance of outer weights. The results (Table 1 and 2) are acceptable as VIFs for all items comprising the second-order composite construct are $<5$ for both groups in both cities (Hair et al., 2017). Further, all outer weights are significant, excluding 'ENV_PR' for the residents of Kashan living within the vicinity of tourism sites. In such circumstances, literature recommends checking the significance of outer loadings to identify insignificant outer weights (Hair et al., 2017). The results show significant outer loadings for all items of the second-order composite construct for both groups and both cities. Therefore, the measurement models are acceptable.

Measurement invariance must be established prior to assessing the structural model and performing MGA to compare path coefficients for both groups of residents (Henseler et al., 2016; Sarstedt et al., 2011). As mentioned prior, literature recommends the measurement invariance of composites (MICOM) approach for composite-based algorithms such as PLSSEM (Henseler et al., 2016). MICOM has three stages: (i) configural invariance assessment, (i) compositional invariance assessment, and (iii) the assessment of equal means and variances (Rasoolimanesh et al., 2017a). Table 5 and 6 show the MICOM results, demonstrating that partial measurement invariance exists for both study areas - a prerequisite to performing MGA. Therefore, the structural model can only be assessed for each group in both study areas, and the structural model for pooled data cannot be reported.

\section{[Table 5]}

[Table 6] 
Assessment of the structural model and multi group analysis

Table 7 shows the structural model assessment and MGA results for residents (i) living in the vicinity of, and (ii) living far from the tourism and heritage tourism sites in Kashan and Tabriz. Two nonparametric approaches to test multi-group differences - bootstrap-based MGA (Henseler et al., 2009) and the permutation test (Chin \& Dibbern, 2010) - were employed to compare path coefficients between groups (Rasoolimanesh et al., 2017a). The results show the positive effects of CAC on RP for both groups of residents in both study areas.

However, the results do not support the hypothesized significant differences for the effect of CAC on RP between residents (i) in the vicinity of and (ii) far from tourism sites (H2). Further, the results demonstrate the positive significant effect of EAT and ECG on RP for both groups of residents, with significant differences between the two groups of residents for these effects ( $\mathbf{H 4}$ and $\mathbf{H 8}$ ). However, the results are consistent across both study areas, and do not indicate significant differences between groups of residents in either Kashan or Tabriz. The results also do not support the significant effects of CAT and INV on RP for both groups of residents in both study areas, with no significant differences identified between these effects (H6 and H10). Therefore, drawing upon data from two cities, this study can crossvalidate results and compare the effects of the aforementioned factors on the perceptions of residents living (i) within the vicinity of and (i) far from heritage tourism sites.

\section{[Table 7]}

Beyond conducting MGA to investigate differences between the effects of CAC, EAT, CAT, ECG, and INV on RP across two resident groups, this study hypothesized and compared the level of CAC, EAT, CAT, ECG, INV, and RP between residents (i) living in the vicinity of, and (ii) living far from tourism sites using a t-test (Table 8). The results identified high levels of CAC, EAT, and CAT in both groups of residents in both study areas (Table 8). Yet, the results only demonstrate significant differences between resident groups in the level of EAT in Kashan, and with regards to CAT in both Kashan and Tabriz. However, these significant differences contradict their associated hypotheses, which proposed higher EAT and CAT for residents living within the vicinity of heritage tourism sites. Therefore, despite identifying significant differences, $\mathbf{H 3}$ and $\mathbf{H 5}$ are also not supported.

Further, the findings show low ECG and INV across both groups of residents and in both study areas. However, they also demonstrate higher levels of ECG and INV for residents 
living far from, compared to those living within the vicinity of, heritage tourism sites. Therefore, while there are significant differences between the levels of ECG and INV in the two groups of residents in both study areas, this again contradicts the associated hypotheses (H7 and H9). Finally, the results indicate high RP for both groups of residents in both study areas, with significant differences between the levels of RP across resident groups. However, residents' perceptions toward tourism development are surprisingly significantly higher for those living far from heritage tourism sites when compared to those living in the vicinity of such sites. Therefore, $\mathbf{H 1 1}$ is rejected.

\section{Discussion}

This study assessed differences between residents living within the vicinity of heritage tourism sites and those living far from heritage tourism sites by focusing on: (i) their perceptions towards tourism development, (ii) the factors influencing their perceptions of tourism development (community attachment, environmental attitude, cultural attitude, economic gain, and involvement), and (iii) the effects of these factors on their perceptions of tourism development.

Underpinned by the central rules of SET, residents living within the vicinity of heritage tourism sites were anticipated to perceive greater economic, social, and cultural returns from inbound tourism, and were thus expected to hold more positive perceptions of the impact of tourism development (Jurowski \& Gursoy, 2004; Mansfeld, 1992). However, this study indicates that the perceptions of residents living far from heritage tourism sites are more positive than those of residents living within the vicinity of heritage tourism sites. This emerged across all factors influencing residents’ perceptions (e.g., community attachment, environmental attitude, cultural attitude, economic gain, and involvement), contradicting some previous studies and the relevant established rules underpinning SET (altruism, group gain, and status consistency) (cf. Besculides et al., 2012; Moghavvemi et al., 2017; Nicholas et al., 2009; Tosun, 2002; Látková \& Vogt, 2012; Rasoolimanesh et al., 2015).

Moreover, residents within the vicinity of tourism sites are expected to hold more favourable perceptions of local heritage assets and are therefore more interested in preserving these assets compared to others, fostering more robust environmental and cultural attitudes (MacKenzie \& Gannon, 2019). Further, residents living within the vicinity of heritage tourism sites often experience greater economic benefit from inbound tourism, and are typically more 
involved in the tourism development process (MacKenzie \& Gannon, 2019). However, the results of this study again contradict this.

The levels of all influencing factors were higher for residents living far from heritage tourism sites compared to those living within the vicinity of the selected sites. These higher levels were significant for EAT, CAT, ECG, and INV. The lower positive perceptions of tourism development for residents living within the vicinity of heritage tourism sites, alongside lower levels of other influencing factors such as CAC, EAT, CAT, ECG, and INV, may stem from residents' perceptions of the negative impacts of increased inbound tourism. Residents living in close proximity to heritage tourism sites may experience the negative economic, social, and environmental impacts of increased tourism (e.g., traffic, pollution, littering, crime) more regularly, with these negative impacts shaping their perceptions and attitudes (MacKenzie \& Gannon, 2019). Thus, these negative impacts, which are expected to be higher for the residents living within the vicinity of heritage tourism sites, may also shape their attitudes toward tourism development, influencing their attachment to local heritage sites assets in the process. Therefore, tourism development may be perceived as the antithesis of the notions of preservation and conservation crucial to heritage management, influencing the environmental and cultural attitudes of residents (e.g., those living within the vicinity of heritage tourism sites) most likely to witness the damage wrought by increased inbound tourism in the process (Bhati \& Pearce, 2017).

Indeed, some residents living within the vicinity of heritage tourism sites may be less inclined to support attempts to preserve local heritage assets because of the negative impacts they perceive stem from tourism development. Moreover, some residents in the vicinity of heritage sites may hold less interest in becoming involved in the process of, tourism development and heritage management based on the negative impacts they may have to endure as a result of increased tourist numbers (Bhati \& Pearce, 2017; MacKenzie \& Gannon, 2019). Therefore, the negative impacts of tourism may serve to explain the unanticipated results, which rejected the related hypotheses comparing the levels of RP, CAC, EAT, CAT, ECG, and INV between residents living within the vicinity of heritage tourism sites and those living far from such sites.

Further, in both Kashan and Tabriz, the results did not support the hypothesized significant differences between the effects of influencing factors (CAC, EAT, CAT, ECG, INV) on RP for residents living within the vicinity of heritage tourism sites and those living far from such sites. The results show the positive effects of CAC, EAT and ECG on RP consistent with previous studies (Gursoy et al., 2002; Rasoolimanesh et al., 2015) for both 
groups of residents in both study areas, whereas the effects of CAT and INV were not significant for both groups in both cities. However, the results demonstrate similar effects for all influencing factors on residents' perceptions for both groups of residents in both study areas. This suggests that the importance and direction of the effects of CAC, EAT, and ECG on RP are similar for residents (i) living in the vicinity of, and (ii) far from heritage tourism sites.

The results showed higher levels of CAC, EAT, CAT, ECG, INV, and RP for residents living far from heritage tourism sites compared to those living within the vicinity of such sites. This emerges for both independent (CAC, EAT, CAT, ECG, and INV) and dependent (RP) variables in the proposed framework, and can perhaps be attributed to the aforementioned perceived negative impacts of tourism development. Nonetheless, the increase in both independent and dependent variables for residents living far from heritage tourism sites leads to similar values (path coefficients) with the effects for residents living within the vicinity of tourism sites. The effect of the negative impacts of tourism development may again stimulate insignificant differences between the effects of CAC, EAT, CAT, ECG, and INV on PR and reject the associated hypotheses (H1, H3, H5, H7, and H9). Therefore, these results contradict previous work confirming the moderating role of distance from heritage tourism sites (Jurowski \& Gursoy, 2004), but are consistent with others (Khoshkam et al., 2016).

\section{Conclusion}

This study investigated the moderating role of residents' distance from heritage tourism sites and the effects of community attachment, environmental and cultural attitudes, economic gain, and involvement on residents' perceptions toward tourism development. Additionally, it investigated differences in the level of the aforementioned factors between residents living within the vicinity of tourism sites and those living further afield. In doing so, it identified a surprising result - residents living far from heritage tourism sites held more favorable environmental and cultural attitudes, perceived greater economic gain from, and had more interest in becoming involved in, the tourism development process.

Further, the findings demonstrate that residents living far from heritage tourism sites also held more positive perceptions toward tourism development when compared to those living in close proximity to these sites. This serves as the key contribution of this study, which may stem from residents living within the vicinity of tourism sites experiencing greater 
exposure to the negative social and environmental impacts of tourism. Additionally, this study identified the insignificant moderating effect of distance from heritage tourism sites for the effects of influencing factors (e.g., community attachment, environmental and cultural attitudes, economic gain, and involvement) on residents' perceptions of tourism development, proffering further significant theoretical contributions.

This study therefore suggests that the negative impacts of tourism can shape residents' perceptions and attitudes toward, and their involvement with and support for, tourism development. It thus identifies the need for tourism planners to develop a greater understanding of the nuances shaping the perceptions and attitudes of residents living within the vicinity of heritage tourism sites. The perceptions, attitudes, involvement, and support of residents living in close proximity to such sites are critical for sustainable tourism development. Therefore, local authorities in Kashan and Tabriz must recognize the needs and desires of those living within the vicinity of their key cultural heritage assets, and should devise and promote initiatives aimed at reducing the perceived negative economic, social, and environmental impacts of tourism. This may influence the environmental and cultural attitudes of residents living within the vicinity of heritage tourism sites, encouraging them to engage with tourism planners in their attempts to preserve the local environment, heritage, and culture.

As such, local authorities must endeavor to improve the awareness and attitudes of those living within the vicinity of heritage sites, stressing the importance and possible benefits of preserving heritage assets, and the positive impact increased tourism can have on residents and their community. Further, they should signpost the economic benefits of tourism to residents living within the vicinity of heritage sites to stimulate support for tourism development. For example, local authorities could incentivize those living in close proximity to heritage tourism sites, recognizing the crucial balance between the economic boon of tourism and the negative impact it can have on residents' everyday lives by offering them reduced taxation, guaranteed free parking, and increased policing and security in order to offset the perceived downsides of tourism development (MacKenzie \& Gannon, 2019).

Further, heritage tourism managers must endeavor to foster a sense of shared ownership and interdependence with residents living in close proximity to their sites. Emphasis should be placed on developing heritage offerings underpinned by regularly changing short-term exhibitions couched within established heritage settings, cognizant of 
local residents' desires and interests. This could encourage residents to visit their local heritage sites more regularly, developing feelings of communal interest and ownership in the process. In doing so, tourism planners may improve the perceptions and attitudes of residents living in the vicinity of heritage tourism sites, subsequently increasing the involvement and support of these residents in the tourism development process.

This study was conducted across two historic cities in Iran to cross-validate the findings, with surprising results. Yet, despite providing a nascent investigation into the heterogeneous attitudes and perceptions toward tourism development held by different resident groups, this study has some limitations. First, the findings cannot be generalized due to geographic specificity. Future studies should concentrate on collecting a wider range of evidence from (i) different geographical contexts or (ii) developed and developing heritage tourism sites to further explore residents' attitudes towards tourism development. Second, this study investigated five factors likely to influence residents' perceptions of tourism development. However, literature identifies multiple antecedents (e.g., sociodemographic characteristics, place identity, awareness and knowledge of tourism, trust), which could also influence perceptions of tourism development. Therefore, investigating how distance moderates the effects of other influencing factors on residents' perceptions of tourism development may proffer avenues for future research. Third, future studies could adopt fuzzyset qualitative comparative analysis and complexity theory to test the proposed relationships. This would identify the combinations of causal conditions underpinning residents' support for tourism development (Gannon, Taheri \& Olya, 2019). Finally, future studies could adopt a qualitative approach to explore why the hypothesized relationships were not supported in greater depth. 


\section{References:}

Andereck, K., \& Nyaupane, G. (2011). Exploring the nature of tourism and quality of life perceptions among residents. Journal of Travel Research, 50(3), 248-260.

Andereck, K., Valentine, K., Knopf, R., \& Vogt, C. (2005). Residents' perceptions of community tourism impacts. Annals of Tourism Research, 32(4), 1056-1076.

Ap, J. (1990). Residents' perceptions research on the social impacts of tourism. Annals of Tourism Research, 17(4), 610-616.

Ap, J. (1992). Residents' perceptions on tourism impacts. Annals of Tourism Research, 19(4), 665-690.

Becker, J.M., Klein, K., \& Wetzels, M. (2012). Hierarchical latent variable models in PLSSEM: guidelines for using reflective-formative type models. Long Range Planning, 45(5-6), 359-394.

Besculides, A., Lee, M., \& McCormick, P.J. (2002). Residents' perceptions of the cultural benefits of tourism. Annals of Tourism Research, 29(2), 303-319.

Bhati, A., \& Pearce, P. (2017). Tourist attractions in Bangkok and Singapore; linking vandalism and setting characteristics. Tourism Management, 63, 15-30.

Boley, B.B., McGehee, N.G., Perdue, R.R. \& Long, P. (2014). Empowerment and resident attitudes toward tourism: Strengthening the theoretical foundation through a Weberian lens. Annals of Tourism Research, 49, 33-40.

Chin, W.W., \& Dibbern, J. (2010). A permutation based procedure for multi-group PLS analysis: Results of tests of differences on simulated data and a cross cultural analysis of the sourcing of information system services between Germany and the USA. In V.Esposito Vinzi, W.W.Chin, J.Henseler \& H.Wang (Eds.), Handbook of Partial Least Squares: Concepts, Methods and Applications (pp.171-193). Heidelberg, Germany: Springer-Verlag.

Cropanzano, R., \& Mitchell, M.S. (2005). Social exchange theory: An interdisciplinary review. Journal of Management, 31(6), 874-900.

Curran, R., Baxter, I., Collinson, E...\& Yalinay, O. (2018). The traditional marketplace: serious leisure and recommending authentic travel. Service Industries Journal. 38(1516), 1116-1132.

Emerson, R. (1976). Social Exchange Theory. Annual Review of Sociology. 2, 335-362.

Faul, F., Erdfelder, E., Buchner, A. and Lang, A.G. (2009) 'Statistical power analyses using G*Power 3.1: Tests for correlation and regression analyses', Behavior Research Methods, 41(4): 1149-60.

de Planhol, X. (2012) Kashan ii. Historical Geography. [online]Encyclopaedia Iranica. Available at: http://www.iranicaonline.org/articles/kashan-ii-historical-geography (Accessed 30/10/2017).

Gannon, M.J., Baxter, I.W., Collinson, E...\& Maxwell-Stuart, R. (2017). Travelling for Umrah: destination attributes, destination image, and post-travel intentions. Service Industries Journal, 37(7-8), 448-465. 
Gannon, M.J., Taheri, B., Olya, H. (2019). Festival quality, self-connection, and bragging. Annals of Tourism Research. 76, 239-252.

Gannon, M.J., Cordina, R., Lochrie, S., Taheri, B. \& Okumus, F. (2019). Kandovan Troglodyte Village: A Functioning Cultural Heritage Experience. In A.Correia, M.Kozak \& A.I.Rodrigues (Eds.) Experiencing Persian Heritage: Perspectives and Challenges (Vol.10, pp.117-134). Bingley, UK: Emerald.

Gursoy, D., Jurowski, C., \& Uysal, M. (2002). Resident attitudes: A structural modeling approach. Annals of Tourism Research, 29(1), 79-105.

Hair, J., Hult, G., Ringle, C., \& Sarstedt, M. (2017). A primer on partial least squares structural equations modeling (PLS-SEM)( $2^{\text {nd }}$ ed.). Los Angeles, CA: SAGE.

Hair, J.F., Risher, J.J., Sarstedt, M., \& Ringle, C.M. (2019). When to use and how to report the results of PLS-SEM. European Business Review, 31(1), 2-24.

Henseler, J., Ringle, C., \& Sarstedt, M. (2016) Testing measurement invariance of composites using partial least squares. International Marketing Review, 33(3), 405-431.

Henseler, J., Ringle, C.M., \& Sarstedt, M. (2015). A new criterion for assessing discriminant validity in Variance-based Structural Equation Modeling. Journal of the Academy of Marketing Science, 43(1), 115-135.

Henseler, J., Ringle, C.M., \& Sinkovics, R.R. (2009). The use of Partial Least Squares Path Modeling in international marketing. In R.R. Sinkovics \& P.N. Ghauri (Eds.), Advances in International Marketing (Vol.20, pp.277-320). Bingley, UK: Emerald

Iranian Cultural Heritage, Handicrafts and Tourism Organization (ICHTO) (2017) 'The National Cultural Heritage List of Iran', ICHTO, Tehran, Iran. [online] Available at: http://www.ichto.ir/Portals/0/r.docx (accessed 06/11/2017).

Jurowski, C., Uysal, M., \& Williams, D.R. (1997). A theoretical analysis of host community resident reactions to tourism. Journal of Travel Research, 36(2), 3-11.

Jurowski, C., \& Gursoy, D. (2004). Distance Effects on Residents' Attitudes Toward Tourism. Annals of Tourism Research, 31(2), 296-312.

Khoshkam, M., Marzuki, A., \& Al-Mulali, U. (2016). Socio-demographic effects on Anzali wetland tourism development. Tourism Management, 54, 96-106.

Látková, P., \& Vogt, C. (2012). Residents' attitudes toward existing and future tourism development in rural communities. Journal of Travel Research, 51(1), 50-67.

Lawler, E., Thye, S. \& Yoon, J. (2008). Social Exchange and Micro Social Order. American Sociological Review. 73, 519-542.

Li, X., \& Wan, Y.K.P. (2017). Residents' support for festivals: Integration of emotional solidarity. Journal of Sustainable Tourism, 25(4), 517-535.

MacKenzie, N. \& Gannon, M. (2019). Exploring the Antecedents of Sustainable Tourism Development. International Journal of Contemporary Hospitality Management. Doi:10.1108/IJCHM-05-2018-0384

Mansfeld, Y. (1992). Group-differentiated perceptions of social impacts related to tourism development. The Professional Geographer, 44(4), 377-392.

Matarrita-Cascante, D., Brennan, M., \& Luloff, A. (2010). Community agency and sustainable tourism development: the case of La Fortuna. Journal of Sustainable Tourism, 18(6), 735-756.

Manyara, G., \& Jones, E. (2007). Community-based tourism enterprises development in Kenya: An exploration of their potential as avenues of poverty reduction. Journal of Sustainable Tourism, 15(6), 628-644.

McGehee, N., \& Andereck, K. (2004). Factors predicting rural residents' support of tourism. Journal of Travel Research, 43(2), 131-140.

Meeker, B.F. (1971). Decisions and exchange. American Sociological Review, 36(3), 485495. 
Moghavvemi, S., Woosnam, K.M., Paramanathan, T., Musa, G., \& Hamzah, A., (2017). The effect of residents' personality, emotional solidarity, and community commitment on support for tourism development. Tourism Management, 63, 242-254.

Nicholas, L., Thapa, B., \& Ko, Y. (2009). Residents' perspectives of a world heritage site: The Pitons Management Area, St. Lucia. Annals of Tourism Research, 36(3), 390412.

Nunkoo, R., Smith, S.L.J., \& Ramkissoon, H. (2013). Residents' attitudes to tourism: A longitudinal study of 140 articles from 1984-2010. Journal of Sustainable Tourism, 21(1), 5-25.

Olya, H.G.T., \& Gavilyan, Y. (2017). Configurational models to predict residents' support for tourism development. Journal of Travel Research, 56(7), 893-912.

Pizam, A. (1978). Tourism's impacts: The social costs to the destination community as perceived by its residents. Journal of Travel Research, 16(4), 8-12.

Rasoolimanesh, S.M., Jaafar, M., Kock, N., \& Ramayah, T. (2015). A revised framework of SET to investigate the factors influencing residents' perceptions. Tourism Management Perspectives, 16, 335-345.

Rasoolimanesh, S.M., \& Jaafar, M. (2017). Sustainable tourism development and residents' perceptions in World Heritage Site destinations. Asia Pacific Journal of Tourism Research, 22(1), 34-48.

Rasoolimanesh, S.M., Roldán, J.L., Jaafar, M., \& Ramayah, T. (2017a). Factors influencing residents' perceptions toward tourism development: Differences across rural and urban world heritage sites. Journal of Travel Research, 56(6), 760-775.

Rasoolimanesh, S.M., Jaafar, M., Kock, N., \& Ahmad, A.G. (2017b). The effects of community factors on residents' perceptions toward World Heritage Site inscription and sustainable tourism development. Journal of Sustainable Tourism, 25(2), 198-216.

Rasoolimanesh, S.M., Jaafar, M., \& Barghi, R. (2017c). Effects of motivation, knowledge and perceived power on residents' perceptions: Application of Weber's theory in World Heritage Site destinations. International Journal of Tourism Research, 19(1), 68-79.

Rasoolimanesh, S.M., Jaafar, M., Ahmad, A.G., \& Barghi, R. (2017d). Community participation in World Heritage Site conservation and tourism development. Tourism Management, 58, 142-153.

Rasoolimanesh, S.M., Noor, S.M. and Jaafar, M. (2019) 'Positive and negative perceptions of residents toward tourism development: Formative or reflective’. In S.Rezaei (ed.) Quantitative Tourism Research in Asia: Current Status and Future Directions. Singapore: Springer.

Reinartz, W., Haenlein, M., \& Henseler, J. (2009). An empirical comparison of the efficacy of covariance-based and variance-based SEM. International Journal of Research in Marketing, 26(4), 332-344.

Ringle, C., Wende, S., \& Becker, J. (2015). SmartPLS3 (Version3.2.3). Boenningstedt, Germany: SmartPLS.

Sarstedt, M., Henseler, J., \& Ringle, C. (2011). Multigroup analysis in partial least squares (PLS) path modeling: Alternative methods and empirical results. Advances in International Marketing, 22, 195-218.

Sharpley, R. (2014). Host perceptions of tourism: A review of the research. Tourism Management, 42, 37-49.

Taheri, B., Gannon, M.J., Cordina, R., \& Lochrie, S. (2018). Measuring host sincerity: scale development and validation. International Journal of Contemporary Hospitality Management, 30(8), 2752-2772.

Taheri, B., Bititci, U., Gannon, M.J. \& Cordina, R. (2019). Investigating the influence of performance measurement on learning, entrepreneurial orientation and performance in 
turbulent markets. International Journal of Contemporary Hospitality Management. 31(3), 1224-1246.

Telfer, D., \& Sharpley, R. (2008). Tourism and development in the developing world. London: Routledge.

Thompson, J., Baxter, I.W.F., Curran, R., \&...Yalinay, O. (2018). Negotiation, bargaining, and discounts: generating WoM and local tourism development at the Tabriz bazaar, Iran. Current Issues in Tourism, 21(11), 1207-1214.

Tosun, C. (2002). Host perceptions of impacts: A comparative tourism study. Annals of Tourism Research, 29(1), 231-253.

Voorhees, C.M., Brady, M.K., Calantone, R., \& Ramirez, E. (2016). Discriminant validity testing in marketing: An analysis, causes for concern, and proposed remedies. Journal of the Academy of Marketing Science, 44(1), 119-134.

Woosnam, K.M. (2011). Testing a model of Durkheim's theory of emotional solidarity among residents of a tourism community. Journal of Travel Research, 50(5), 546-558.

Woosnam, K.M., Draper, J., Jiang, J., Aleshinloye, K.D., \& Erul, E. (2018). Applying selfperception theory to explain residents' attitudes about tourism development through travel histories. Tourism Management, 64, 357-368.

UNESCO (2017a) The State Parties: Iran. [online] UNESCO, World Heritage Center. Available at: http://whc.unesco.org/en/statesparties/ir (Accessed 01/11/2017).

UNESCO (2017b) Iran and the 2003 Convention. [online] UNESCO, Intangible Cultural Heritage Lists. Available at: https://ich.unesco.org/en/state/iran-islamic-republic-of-IR (Accessed 01/11/2017).

UNESCO (2019) Tabriz Historic Bazaar Complex. [online] UNESCO World Heritage List. Available at: https://whc.unesco.org/en/list/1346. (Accessed 04/02/2019).

Zuo, B., Gursoy, D., \& Wall, G. (2017). Residents' support for red tourism in China: The moderating effect of central government. Annals of Tourism Research, 64, 51-63. 
Figure 1. Conceptual Framework

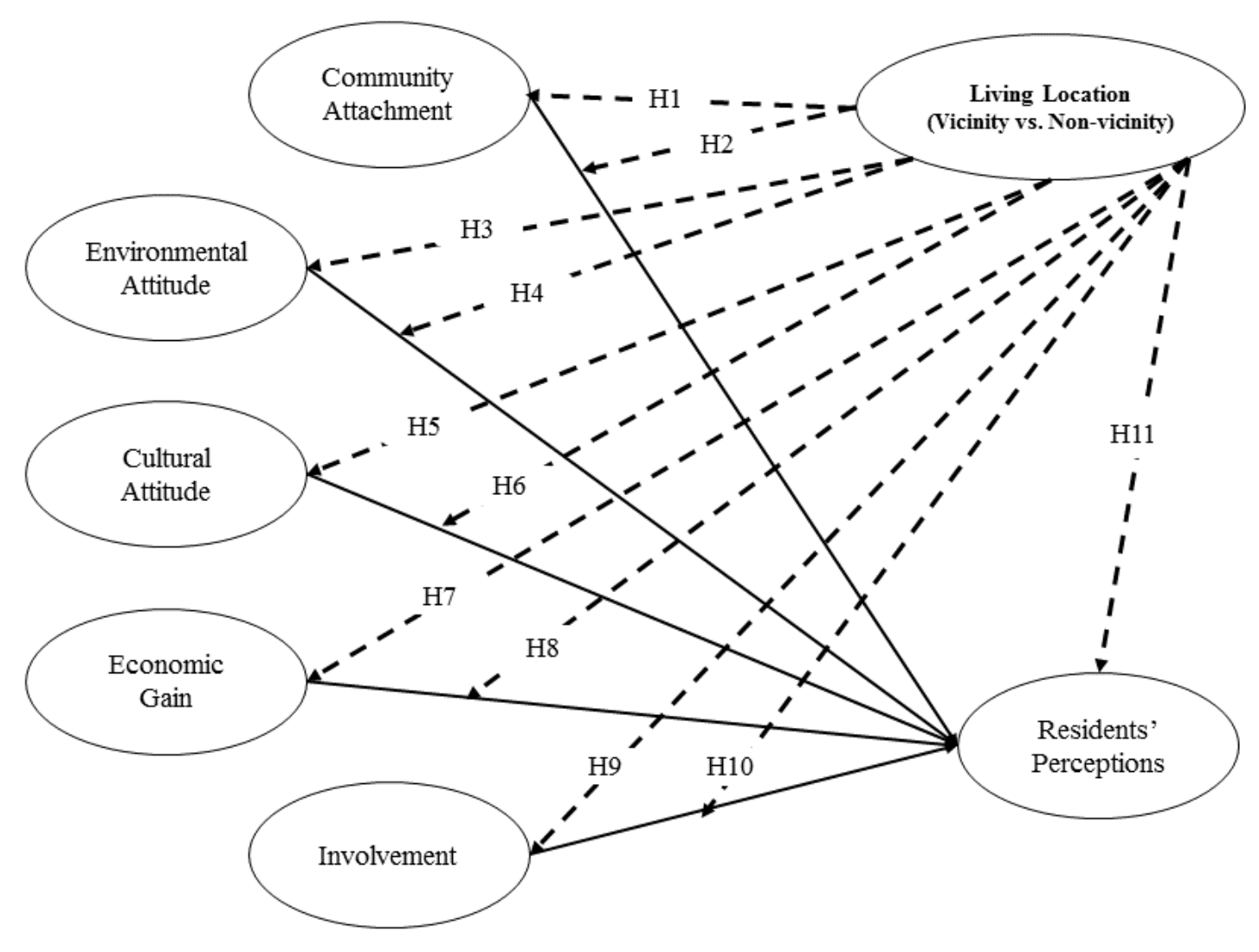

Note: Dashed lines show the hypotheses and differences between residents living in the vicinity and far from tourism sites for the relationships and constructs. 
Table 1. Measurement Model Assessment Results (Kashan)

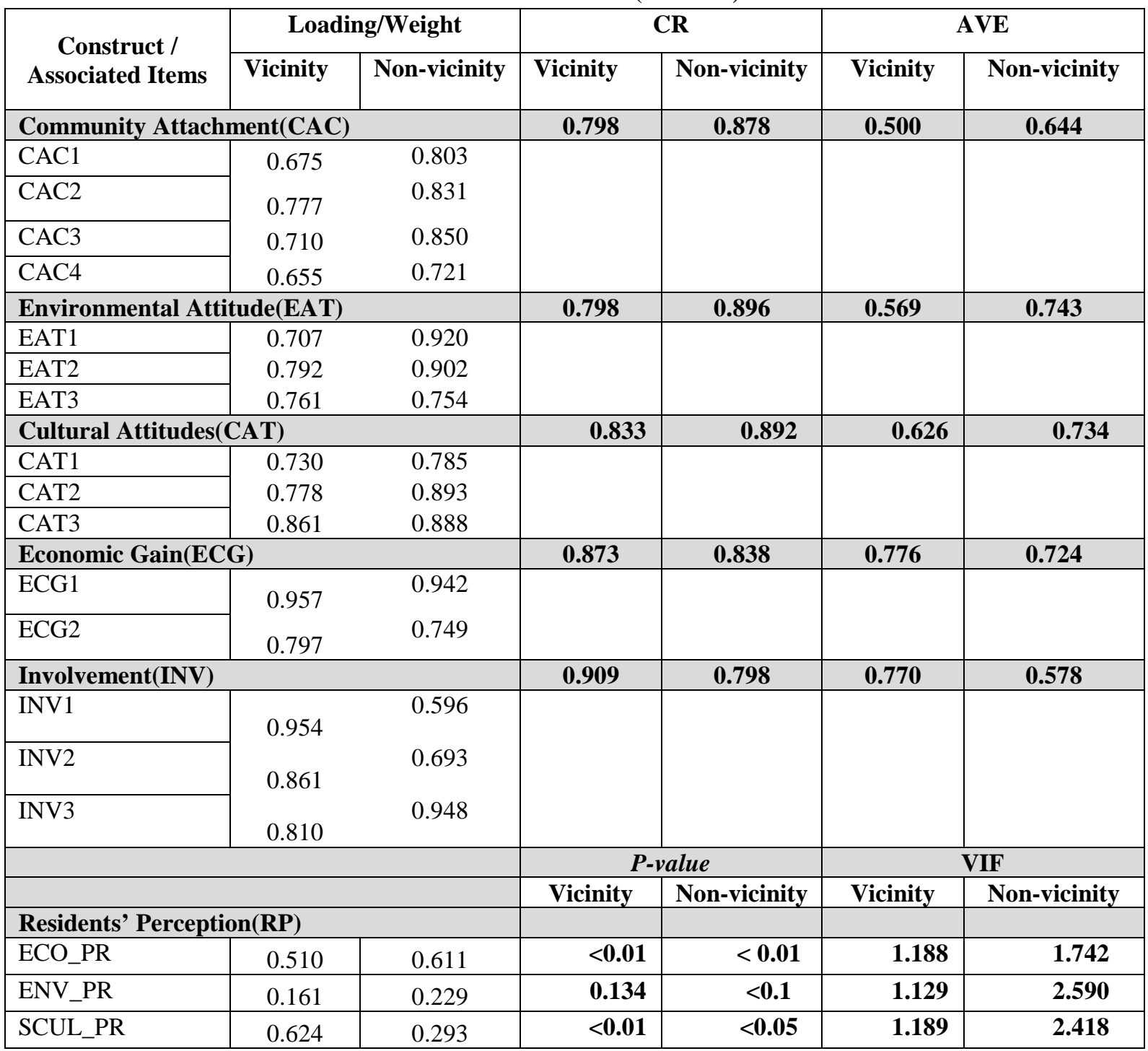

Note: See Appendix 1 for the names of the items 
Table 2. Measurement Model Assessment Results (Tabriz)

\begin{tabular}{|c|c|c|c|c|c|c|}
\hline \multirow{2}{*}{$\begin{array}{c}\text { Construct/ } \\
\text { Associated Items }\end{array}$} & \multicolumn{2}{|c|}{ Loading/Weight } & \multicolumn{2}{|c|}{$\mathbf{C R}$} & \multicolumn{2}{|c|}{ AVE } \\
\hline & Vicinity & Non-vicinity & Vicinity & Non-vicinity & Vicinity & Non-vicinity \\
\hline \multicolumn{3}{|c|}{ Community Attachment(CAC) } & 0.817 & 0.865 & 0.529 & 0.617 \\
\hline CAC1 & \multirow{4}{*}{\multicolumn{2}{|c|}{$\begin{array}{l}0.712 \\
0.778 \\
0.787 \\
0.621 \\
\end{array}$}} & & & & \\
\hline CAC2 & & & & & & \\
\hline CAC3 & & & & & & \\
\hline CAC4 & & & & & & \\
\hline \multicolumn{3}{|c|}{ Environmental Attitude(EAT) } & 0.828 & 0.843 & 0.617 & 0.643 \\
\hline EAT1 & \multirow{3}{*}{\multicolumn{2}{|c|}{$\begin{array}{l}0.706 \\
0.839 \\
0.805 \\
\end{array}$}} & & & & \\
\hline EAT2 & & & & & & \\
\hline EAT3 & & & & & & \\
\hline \multicolumn{3}{|c|}{ Cultural Attitudes(CAT) } & 0.853 & 0.846 & 0.660 & 0.647 \\
\hline CAT1 & \multirow{3}{*}{\multicolumn{2}{|c|}{$\begin{array}{l}0.765 \\
0.858 \\
0.812 \\
\end{array}$}} & & & & \\
\hline CAT2 & & & & & & \\
\hline CAT3 & & & & & & \\
\hline \multicolumn{3}{|c|}{ Economic Gain(ECG) } & 0.816 & 0.850 & 0.696 & 0.740 \\
\hline ECG1 & \multirow{2}{*}{\multicolumn{2}{|c|}{$\begin{array}{l}0.962 \\
0.682\end{array}$}} & & & & \\
\hline ECG2 & & & & & & \\
\hline \multicolumn{3}{|l|}{ Involvement(INV) } & 0.875 & 0.858 & 0.701 & 0.670 \\
\hline INV1 & \multirow{5}{*}{$\begin{array}{l}0.912 \\
0.784 \\
0.811 \\
\end{array}$} & 0.747 & & & & \\
\hline INV2 & & 0.790 & & & & \\
\hline INV3 & & 0.909 & & & & \\
\hline & & & \multicolumn{2}{|c|}{ P-value } & \multicolumn{2}{|c|}{ VIF } \\
\hline & & & Vicinity & Non-vicinity & Vicinity & Non-vicinity \\
\hline \multicolumn{7}{|c|}{ Residents' Perception(RP) } \\
\hline ECO_PR & 0.653 & 0.474 & $<0.01$ & $<0.01$ & 1.272 & 1.536 \\
\hline ENV_PR & 0.120 & 0.405 & $<0.1$ & $<0.01$ & 1.228 & 1.875 \\
\hline SCUL_PR & 0.455 & 0.305 & $<0.01$ & $<0.01$ & 1.365 & 1.849 \\
\hline
\end{tabular}

Note: See Appendix 1 for full items 
Table 3. Discriminant Validity (HTMT)(Kashan)

\begin{tabular}{|c|c|c|c|c|c|c|c|c|c|c|}
\hline \multirow{2}{*}{ Constructs } & CAC & EAT & CAT & ECG & INV & CAC & EAT & CAT & ECG & $\overline{\text { INV }}$ \\
\hline & \multicolumn{5}{|c|}{ Vicinity } & \multicolumn{5}{|c|}{ Non-vicinity } \\
\hline \multicolumn{11}{|l|}{ CAC } \\
\hline EAT & 0.298 & & & & & 0.612 & & & & \\
\hline CAT & 0.276 & 0.482 & & & & 0.604 & 0.592 & & & \\
\hline ECG & 0.158 & 0.205 & 0.171 & & & 0.377 & 0.228 & 0.301 & & \\
\hline INV & 0.291 & 0.186 & 0.142 & 0.739 & & 0.202 & 0.118 & 0.178 & 0.680 & \\
\hline
\end{tabular}

Table 4. Discriminant Validity (HTMT)(Tabriz)

\begin{tabular}{|c|c|c|c|c|c|c|c|c|c|c|}
\hline \multirow{2}{*}{ Constructs } & CAC & EAT & CAT & ECG & INV & CAC & EAT & CAT & ECG & INV \\
\hline & \multicolumn{5}{|c|}{ Vicinity } & \multicolumn{5}{|c|}{ Non-vicinity } \\
\hline \multicolumn{11}{|l|}{$\overline{\mathrm{CAC}}$} \\
\hline EAT & 0.478 & & & & & 0.530 & & & & \\
\hline CAT & 0.423 & 0.613 & & & & 0.509 & 0.559 & & & \\
\hline ECG & 0.134 & 0.229 & 0.273 & & & 0.228 & 0.203 & 0.302 & & \\
\hline INV & 0.081 & 0.149 & 0.114 & 0.782 & & 0.056 & 0.106 & 0.172 & 0.728 & \\
\hline
\end{tabular}


Table 5. Results of invariance measurement testing using permutation (Kashan)

\begin{tabular}{|c|c|c|c|c|c|c|c|c|c|c|c|}
\hline \multirow[t]{2}{*}{ Constructs } & \multirow{2}{*}{$\begin{array}{l}\text { Configural } \\
\text { invariance } \\
\text { (Same algorithms } \\
\text { for both groups) }\end{array}$} & \multicolumn{2}{|c|}{$\begin{array}{l}\text { Compositional invariance } \\
(\text { Correlation }=1)\end{array}$} & \multirow{2}{*}{$\begin{array}{l}\text { Partial } \\
\text { measurement } \\
\text { invariance } \\
\text { established }\end{array}$} & \multicolumn{3}{|c|}{ Equal mean assessment } & \multicolumn{3}{|c|}{ Equal variance assessment } & \multirow{2}{*}{$\begin{array}{l}\text { Full } \\
\text { measurement } \\
\text { invariance } \\
\text { established }\end{array}$} \\
\hline & & $\mathrm{C}=1$ & $\begin{array}{l}\text { Confidence } \\
\text { Interval (CIs) }\end{array}$ & & Differences & $\begin{array}{l}\text { Confidence } \\
\text { Interval (CIs) }\end{array}$ & Equal & Differences & $\begin{array}{l}\text { Confidence } \\
\text { Interval (CIs) }\end{array}$ & Equal & \\
\hline CAC & Yes & 0.986 & {$[0.977,1.000]$} & Yes & 0.142 & {$[-0.199,0.191]$} & Yes & 0.467 & {$[-0.440,0.425]$} & No & No \\
\hline EAT & Yes & 0.999 & {$[0.987,1.000]$} & Yes & 0.430 & {$[-0.195,0.192]$} & No & -0.009 & {$[-0.374,0.349]$} & Yes & No \\
\hline CAT & Yes & 0.987 & {$[0.980,1.000]$} & Yes & 0.374 & {$[-0.191,0.193]$} & No & -0.094 & {$[-0.410,0.394]$} & Yes & No \\
\hline ECG & Yes & 1.000 & {$[0.981,1.000]$} & Yes & 0.496 & {$[-0.200,0.197]$} & No & 0.153 & {$[-0.202,0.197]$} & Yes & No \\
\hline INV & Yes & 0.891 & {$[0.708,1.000]$} & Yes & 0.432 & {$[-0.193,0.200]$} & No & -0.125 & {$[-0.187,0.177]$} & Yes & No \\
\hline $\mathrm{RP}$ & Yes & 0.973 & {$[0.941,1.000]$} & Yes & 0.408 & {$[-0.197,0.192]$} & No & 0.810 & {$[-0.443,0.446]$} & No & No \\
\hline
\end{tabular}

Table 6. Results of invariance measurement testing using permutation (Tabriz)

\begin{tabular}{|c|c|c|c|c|c|c|c|c|c|c|c|}
\hline \multirow[t]{2}{*}{ Constructs } & \multirow{2}{*}{$\begin{array}{l}\text { Configural } \\
\text { invariance } \\
\text { (Same algorithms } \\
\text { for both groups) }\end{array}$} & \multicolumn{2}{|c|}{$\begin{array}{l}\text { Compositional invariance } \\
(\text { Correlation=1) }\end{array}$} & \multirow{2}{*}{$\begin{array}{l}\text { Partial } \\
\text { measurement } \\
\text { invariance } \\
\text { established }\end{array}$} & \multicolumn{3}{|c|}{ Equal mean assessment } & \multicolumn{3}{|c|}{ Equal variance assessment } & \multirow{2}{*}{$\begin{array}{l}\text { Full } \\
\text { measurement } \\
\text { invariance } \\
\text { established }\end{array}$} \\
\hline & & $\mathrm{C}=1$ & $\begin{array}{l}\text { Confidence } \\
\text { Interval (CIs) }\end{array}$ & & Differences & $\begin{array}{l}\text { Confidence } \\
\text { Interval (CIs) }\end{array}$ & Equal & Differences & $\begin{array}{l}\text { Confidence } \\
\text { Interval (CIs) }\end{array}$ & Equal & \\
\hline CAC & Yes & 0.998 & {$[0.983,1.000]$} & Yes & 0.147 & {$[-0.171,0.177]$} & Yes & 0.202 & {$[-0.397,0.376]$} & Yes & Yes \\
\hline EAT & Yes & 0.990 & {$[0.987,1.000]$} & Yes & 0.115 & {$[-0.172,0.171]$} & Yes & -0.095 & {$[-0.303,0.291]$} & Yes & Yes \\
\hline CAT & Yes & 1.000 & {$[0.982,1.000]$} & Yes & 0.153 & {$[-0.174,0.168]$} & Yes & -0.080 & {$[-0.349,0.334]$} & Yes & Yes \\
\hline ECG & Yes & 0.989 & {$[0.980,1.000]$} & Yes & 0.172 & {$[-0.179,0.174]$} & Yes & 0.136 & {$[-0.183,0.177]$} & Yes & Yes \\
\hline INV & Yes & 0.952 & {$[0.669,1.000]$} & Yes & 0.190 & {$[-0.176 .0 .179]$} & No & -0.041 & {$[-0.169,0.158]$} & Yes & No \\
\hline $\mathrm{RP}$ & Yes & 0.964 & {$[0.952,1.000]$} & Yes & 0.190 & {$[-0.173,0.173]$} & No & 0.354 & {$[-0.378,0.365]$} & Yes & No \\
\hline
\end{tabular}


Table 7. Results of Hypothesis Testing (MGA results for relationships)

\begin{tabular}{|c|c|c|c|c|c|c|c|c|c|c|c|c|c|c|c|}
\hline \multirow{3}{*}{ Hypothesis } & \multirow{3}{*}{ Relationships } & \multicolumn{4}{|c|}{ Path Coefficient } & \multicolumn{4}{|c|}{$\begin{array}{c}\text { Confidence Interval(95\%) } \\
\text { Bias Corrected }\end{array}$} & \multicolumn{4}{|c|}{$\begin{array}{l}P \text {-value Difference } \\
\text { (one-tailed) }\end{array}$} & \multirow{2}{*}{\multicolumn{2}{|c|}{ Supported }} \\
\hline & & \multicolumn{2}{|c|}{ Kashan } & \multicolumn{2}{|c|}{ Tabriz } & \multicolumn{2}{|c|}{ Kashan } & \multicolumn{2}{|c|}{ Tabriz } & \multicolumn{2}{|c|}{ Henseler's MGA } & \multicolumn{2}{|c|}{ Permutation test } & & \\
\hline & & Vicinity & $\begin{array}{c}\text { Non- } \\
\text { vicinity }\end{array}$ & Vicinity & $\begin{array}{c}\text { Non- } \\
\text { vicinity }\end{array}$ & Vicinity & Non-vicinity & Vicinity & Non-vicinity & Kashan & Tabriz & Kashan & Tabriz & Kashan & Tabriz \\
\hline $\mathbf{H} 2$ & $\mathrm{CAC} \rightarrow \mathrm{RP}$ & 0.138 & 0.299 & 0.196 & 0.272 & {$[-0.004,0.233]$} & {$[0.122,0.462]$} & {$[0.100,0.286]$} & {$[0.095,0.435]$} & 0.099 & 0.258 & 0.203 & 0.526 & No & No \\
\hline H4 & $\mathrm{EAT} \rightarrow \mathrm{RP}$ & 0.340 & 0.366 & 0.372 & 0.296 & {$[0.235,0.447]$} & {$[0.187,0.555]$} & {$[0.288,0.454]$} & {$[0.142,0.442]$} & 0.415 & 0.764 & 0.836 & 0.448 & No & No \\
\hline H6 & $\mathrm{CAT} \rightarrow \mathrm{RP}$ & 0.032 & -0.107 & 0.084 & -0.062 & {$[-0.127,0.145]$} & {$[-0.220,0.044]$} & {$[-0.038,0.202]$} & $-0.198,0.077]$ & 0.883 & 0.896 & 0.255 & 0.203 & No & No \\
\hline H8 & $\mathrm{ECG} \rightarrow \mathrm{RP}$ & 0.321 & 0.311 & 0.273 & 0.331 & {$[0.197,0.467]$} & {$[0.192,0.438]$} & {$[0.173,0.369]$} & {$[0.243,0.444]$} & 0.545 & 0.252 & 0.921 & 0.513 & No & No \\
\hline H10 & $\mathrm{INV} \rightarrow \mathrm{RP}$ & 0.048 & -0.030 & 0.023 & 0.052 & {$[-0.261,0.085]$} & {$[-0.291,0.181]$} & $-0.166,0.094]$ & {$[-0.122,0.134]$} & 0.281 & 0.387 & 0.432 & 0.717 & No & No \\
\hline
\end{tabular}

Note: In Henseler's MGA method, the p value lower than 0.05 or higher than 0.95 indicates at the $5 \%$ level significant differences between specific path coefficients across two groups.

Table 8. Results of Hypothesis Testing (t-test results for constructs)

\begin{tabular}{|c|c|c|c|c|c|c|c|c|c|c|c|c|c|}
\hline \multirow{2}{*}{ Hypothesis } & \multirow{2}{*}{ Constructs } & \multicolumn{2}{|c|}{$\begin{array}{l}\text { Mean Value } \\
\text { Kashan }\end{array}$} & \multicolumn{2}{|c|}{$\begin{array}{c}\text { Mean Value } \\
\text { Tabriz }\end{array}$} & \multirow{2}{*}{$\begin{array}{l}\text { Mean value } \\
\text { differences } \\
\text { (Kashan) }\end{array}$} & \multirow{2}{*}{$\begin{array}{l}\text { Mean value } \\
\text { differences } \\
\text { (Tabriz) }\end{array}$} & \multicolumn{2}{|c|}{ Kashan } & \multicolumn{2}{|r|}{ Tabriz } & \multicolumn{2}{|c|}{ Supported } \\
\hline & & Vicinity & $\begin{array}{c}\text { Non- } \\
\text { vicinity }\end{array}$ & Vicinity & $\begin{array}{c}\text { Non- } \\
\text { vicinity }\end{array}$ & & & t-value & $\mathbf{C I}_{0.95}$ & t-value & $\mathbf{C I}_{0.95}$ & Kashan & Tabriz \\
\hline H1 & CAC & 4.167 & 4.265 & 4.178 & 4.283 & -0.0984 & -0.1049 & 1.410 & {$[-0.351,0.58]$} & 1.621 & {$[-0.317,0.030]$} & No & No \\
\hline H3 & EAT & 4.225 & 4.516 & 4.333 & 4.408 & -0.2917 & -0.0745 & 4.396 & {$[-0.634,-0.242]$} & 1.319 & {$[-0.287,0.056]$} & No (different sign) & No \\
\hline H5 & CAT & 4.020 & 4.316 & 4.115 & 4.228 & -0.2957 & -0.113 & 3.793 & {$[-0.585,-0.186]$} & 1.715 & {$[-0.318,0.022]$} & No (different sign) & No (different sign) \\
\hline H7 & ECG & 2.671 & 3.183 & 2.939 & 3.103 & -0.5125 & -0.164 & 5.086 & {$[-0.693,-0.307]$} & 1.917 & {$[-0.346,0.004]$} & No (different sign) & No (different sign) \\
\hline H9 & INV & 2.497 & 3.041 & 2.707 & 2.941 & -0.5441 & -0.233 & 4.363 & {$[-0.617,-0.234]$} & 2.162 & {$[-0.366,-0.017]$} & No (different sign) & No (different sign) \\
\hline H11 & $\mathrm{RP}$ & 3.956 & 4.197 & 4.070 & 4.163 & -0.2408 & -0930 & 3.811 & {$[-0.618,-0.197]$} & 2.120 & {$[-0.361,-0.014]$} & No (different sign) & No (different sign) \\
\hline
\end{tabular}


Appendix 1. Adapted items

\begin{tabular}{|c|c|}
\hline & Questions \\
\hline & Community Attachment \\
\hline CAC1 & I have positive feelings for Kashan/Tabriz. \\
\hline CAC2 & I feel a sense of belonging to this place. \\
\hline CAC3 & I have an emotional attachment to this place- it has meaning to me. \\
\hline \multirow[t]{2}{*}{ CAC4 } & I am willing to invest my talent or time to make this an even better place. \\
\hline & Environmental Attitude \\
\hline EAT1 & The diversity of heritage must be valued and protected. \\
\hline EAT2 & Community environment must be protected now and in the future. \\
\hline \multirow[t]{2}{*}{ ЕАТЗ } & $\begin{array}{l}\text { The development of infrastructure and public facilities, as well private sector, should not } \\
\text { damage heritage areas. }\end{array}$ \\
\hline & Cultural Attitude \\
\hline CAT1 & The local and traditional culture should be preserved. \\
\hline CAT2 & The lifestyle of local residents should be protected. \\
\hline \multirow[t]{2}{*}{ САT3 } & My traditions and culture are very important for me. \\
\hline & Economic Gain \\
\hline ECG1 & Increasing the number of visitors in Tabriz/Kashan affects my current household income. \\
\hline \multirow[t]{2}{*}{ ECG2 } & A high percentage of my current income comes from money spent by visitors. \\
\hline & Involvement \\
\hline INV1 & The residents of Tabriz/Kashan have been involved in the management of heritage. \\
\hline INV2 & $\begin{array}{l}\text { The residents of Tabriz/Kashan have been involved in the process of tourism development and } \\
\text { planning }\end{array}$ \\
\hline \multirow[t]{2}{*}{ INV3 } & Most of time my opinions have been asked regarding planning and development of tourism. \\
\hline & Economic Perceptions \\
\hline ECO_RP1 & Tourism development creates more jobs for my community. \\
\hline ECO_RP2 & Tourism development attracts more investment to my community. \\
\hline ECO_RP3 & Our standard of living increases considerably because of tourism. \\
\hline \multirow[t]{2}{*}{ ECO_RP4 } & $\begin{array}{l}\text { Tourism development provides more infrastructures and public facilities (roads, shopping } \\
\text { malls, etc.). }\end{array}$ \\
\hline & Environmental Perceptions \\
\hline & Tourism development: \\
\hline ENV_RP1 & ...helps to preserve the natural environment \\
\hline ENV_RP2 & ...helps to preserve the historical buildings \\
\hline \multirow[t]{3}{*}{ ENV_RP3 } & ...improves the area's appearance \\
\hline & Socio-Cultural Perceptions \\
\hline & Tourism development: \\
\hline SCUL_RP1 & ...preserves the cultural identity of host residents. \\
\hline SCUL_RP2 & ...promotes cultural exchange. \\
\hline SCUL_RP3 & ...facilitates meeting visitors and educational experiences. \\
\hline SCUL_RP4 & ...increases recreation facilities and opportunities. \\
\hline
\end{tabular}

